\title{
Gendered impacts of greenhouse gas mitigation options for rice cultivation in India
}

\author{
Hom Gartaula ${ }^{1}$ (D) - Tek B Sapkota ${ }^{2}$ - Arun Khatri-Chhetri ${ }^{3} \cdot$ Gokul Prasad $^{4}$. \\ Lone Badstue ${ }^{2}$
}

Received: 10 June 2020 / Accepted: 5 November 2020/

(C) The Author(s) 2020, corrected publication 2020

\begin{abstract}
The nexus of gender-agriculture-emissions reduction is one of the least explored areas related to agriculture and climate change. This nexus plays an important role in the areas where women's participation in agriculture is high, and the contribution of the agricultural sector to total emission is significant. This study generates evidence on women's labor contribution in rice cultivation and potential reduction of their labor drudgery, including GHG mitigation co-benefits with the adoption of direct seeding and machine transplanting technologies. Using a large number of plot-level data (11,987 data points) from the rice-growing regions of India, the study shows that changing rice production technology from conventional to direct-seeded rice (DSR) and/or machine-transplanted rice (MTR) offers huge potential to reduce women's labor in rice planting (745 million labor-days for DSR and 610 million labor-days for MTR) and greenhouse gases (GHG) emission (34 $\mathrm{MtCO}_{2} \mathrm{e}$ for DSR and $7 \mathrm{MtCO}_{2} \mathrm{e}$ for MTR) at the same time. This potential differs from the agro-ecological region, the level of input use, and women's involvement in rice cultivation. The realization of this gender-responsive GHG mitigation strategy depends on the adoption of these technologies, which rely on several social, economic, and political factors. At the same time, the immense potential for negative implications for some specific groups should not be ignored, but focused on addressing and mitigating those challenges.
\end{abstract}

Keywords Climate change $\cdot$ Gender-responsive mitigation $\cdot$ Co-benefits $\cdot$ Rice cultivation $\cdot$ India

Hom Gartaula

h.gartaula@cgiar.org

1 International Maize and Wheat Improvement Centre (CIMMYT), New Delhi, India

2 International Maize and Wheat Improvement Centre (CIMMYT), El Batan, Mexico

3 International Center of Tropical Agriculture (CIAT), Cali, Colombia

4 Thünen Institute of Climate-Smart Agriculture, Braunschweig, Germany 


\section{Introduction}

The global community is looking for new approaches to integrate gender considerations in emission reduction options across the agricultural production systems that can help reduce women's drudgery as well as greenhouse gas (GHG) emissions (IUCN 2015; UNFCCC 2019). However, the nexus of gender-agriculture-emissions reduction is one of the least explored areas.

Many women in developing countries are involved in agricultural production systems for their livelihoods. Any technological and managerial interventions can directly or indirectly affect them. Globally, arable agriculture (excluding forestry and other land uses) contributes to approximately $12 \%$ of the total GHG emissions (IPCC 2019). Rice cultivation is the 4th largest source of GHG emissions in agriculture after enteric fermentation (40\%), livestock manure management (23\%), and fertilizer use in croplands and grasslands (13\%) (FAO 2017). Women's significant role in rice cultivation, specifically transplanting, is well documented (Paris 1998; Datta and Rustagi 2012; Mohanty et al. 2012; Kumar et al. 2018, Khatri-Chhetri et al. 2020). The rice transplanting and associated activities account for up to $22 \%$ of the total time spent by women family members and $46 \%$ of women wage laborers (Mohanty et al. 2012). Several studies show that women contribute significantly more labor in rice cultivation than men (GRiSP 2013; Mishra et al. 2017; Connor and San 2020), and in some locations, women may contribute all labor required for rice transplanting (Khatri-Chhetri et al. 2020). Hence, combining the reduction of women's labor-burden and GHG emissions from rice cultivation could have significant social, economic, and environmental implications in ricegrowing areas.

The rice cultivation areas spanning the Indian sub-continent, China, and Southeast Asia account for around $90 \%$ of the world's rice production (Chakraborty et al. 2017). Globally, India ranks 1st with approximately 44 million hectares under rice cultivation (SRD 2020). Rice production in India is responsible for the emission of 97 megaton carbon dioxide equivalent $\left(\mathrm{MtCO}_{2} \mathrm{e}\right)$ per year $(\mathrm{FAO} 2017)$. Methane $\left(\mathrm{CH}_{4}\right)$ and nitrous oxide $\left(\mathrm{N}_{2} \mathrm{O}\right)$ are the primary GHGs released from rice cultivation, with a respective global warming potential of 28 and 265 times higher than that of carbon dioxide $\left(\mathrm{CO}_{2}\right)$ in 100 years' time horizon (IPCC 2013). In India, although the livestock sector contributes to the higher share of agricultural emission, the crop sector, including rice management, offers higher mitigation potential (Sapkota et al., 2019). Rice in India is mainly grown by transplanting 25-30-day-old seedlings into puddled soil, which involves repeated tillage of pounded soil to create a soft mud (Gathala et al. 2011). Although this practice provides many benefits to rice, the creation of hardpan in shallow depth reduces the percolation of water. The long duration of standing water in the rice field creates an anaerobic situation congenial for methane production and emission (Masscheleyn et al. 1993).

Along with the reduced labor force and increased labor wage resulting from urban expansion in India, there is an acute shortage of labor for manual rice transplanting. This results in delayed transplanting in many areas while some areas remain uncultivated. Considering the importance of rice as a staple food crop for the large population, researchers have developed and promoted new technologies for high yield, low labor requirement, and low emission. Recent studies recommend various low emission and less labor-intensive options for rice cultivation (Aryal et al. 2020; Jat et al. 2019; Sapkota et al. 2019).

Direct-seeded rice (DSR) involves sowing rice seeds directly in the field with or without preparatory tillage using a seed-cum-fertilizer drill or happy turbo seeder (Farooq et al. 2011; Sidhu et al. 2015). Changing rice production technology from conventional transplanting 
(CTR) to DSR can reduce a significant amount of GHG emissions from rice fields (Chakraborty et al. 2017; Gupta et al. 2016; Kumar et al. 2016). Likewise, machine transplanting (MTR) is another technology where rice seedlings grown in a mat-nursery are transplanted using a self-propelled rice transplanter. It also reduces GHG emissions by reducing preparatory tillage and puddling (Rickman et al. 2015).

Changing rice production technology from CTR to DSR and/or MTR can help reduce labor drudgery; however, it is important to consider who benefits from such technological changeand who does not (Doss 2001). Men and women are responsible for different tasks during rice cultivation, such as nursery raising, transplanting, intercultural, and postharvest operations. The introduction of MTR and DSR may have positive or negative impacts on men and/or women farmers, which is determined by their social positioning and how they maneuver change. Literature shows that DSR reduces labor requirements, increases yield and profitability, saves seeds, and reduces carbon emissions (Joshi et al. 2019). As such, technological solutions to mitigate GHG emissions and reduce drudgery have opportunities and trade-offs for equitable benefits (Beuchelt and Badstue 2013).

Studies of labor in rice production reveal that women contribute as much as $60-80 \%$ of the total labor requirement in the Indian sub-continent (GRiSP 2013). In rice cultivation, women significantly contribute to transplanting, weeding, and harvesting activities (Khatri-Chhetri et al. 2020; Kumar et al. 2018; Mohanty et al. 2012). MTR can reduce the cost of cultivation up to $45-50 \%$, labor requirements up to $75-80 \%$ (Das 2012), and women's drudgery up to $83 \%$ (Ojha and Kwatra 2014). Adoption of DSR or MTR together with changes in irrigation practices (e.g., alternate drying and wetting) and nutrient management (precision nutrient management) has been shown to reduce a large amount of emissions from rice cultivation (Balaine et al. 2019; Kamboj et al. 2013). Therefore, the replacement of manual transplanting by DSR and MTR can reduce both women's drudgery and GHG emissions.

The literature on gender dimensions of climate-smart agricultural practices is growing. For example, scholars report changing nutritional outcomes of men and women farmers through cropping system diversification and soil and water conservation in Ethiopia (Teklewold et al. 2019), or new rice and pulse varieties as best management practices (Connor and San 2020). Others observed women benefiting from the use of labor-saving technologies like weeders (Hansda 2017), DSR (Joshi et al. 2019), or MTR (Akter et al. 2017). However, the gender and emission dimension of changing CTR into DSR and/or MTR is very limited to our knowledge. This study looks at the interface between women's drudgery reduction and GHG emissions for the adoption of climate-smart technologies like DSR and MTR. The study provides rich information to policymakers for targeting locations and investments to make rice production labor-efficient, reduce drudgery to women farmers, and minimize GHG emissions from rice cultivation.

\section{Methods}

\subsection{Study site}

The study was conducted in India, covering all rice-producing districts. West Bengal, Uttar Pradesh, Punjab, Odisha, and Andhra Pradesh are among the top five rice-growing states by total production. The rice-growing areas span the western and eastern coastal strips covering all the primary deltas, low hills and foothills of the Tarai region, and the delta of the Indo- 
Gangetic Plains. The large irrigation systems connected with perennial rivers across the country provide options to cultivate two rice crops per year in many areas, even three rice crops a year in some places. In many locations, the rice yields have significantly increased in recent decades with high-yielding varieties, enhanced planting methods, regular water supply, and the use of chemical fertilizers. From 1961 to 2018, the rice yield increased by $1.21 \%$, while the total emissions from rice production during that period grew at $0.36 \%$ annually in India (FAO 2020).

\subsection{Data sources}

Rice production-related input data from all rice-growing areas in India were taken from the cost of cultivation survey conducted by the Ministry of Agriculture and Farmers Welfare, Government of India ${ }^{1}$. A total of 11,987 geo-referenced plot-level data (Fig. 1) on inputs and crop management for the year 2013 formed the foundation of the activity data used in GHG estimation and labor requirement. District-wise rice area for the same year was also obtained from the Ministry of Agriculture and Farmers Welfare website ${ }^{2}$. As the total area under rice cultivation has not changed significantly from 2013 to 2018 (FAO 2019), the area under rice cultivation in 2013 represents the current rice cultivation area in all districts. Of the various information available in this database, field-specific information on tillage and crop establishment and crop management, including fertilizer and residue management, was taken for estimating the GHG emission. The plot-specific soil data such as texture, soil organic carbon, soil $\mathrm{pH}$, and bulk density were drawn from the International Soil Reference and Information Centre database (Hengl et al. 2017). The climate information for the study sites was based on the Koppen classification system ${ }^{3}$. Spatially explicit water management practice under CTR systems was based on Huke and Huke (1997), Gupta et al. (2009), and Bhatia et al. (2013) and that under DSR and MTR was based on CIMMYT's field experiences (e.g., Jat et al. 2014; Sapkota et al. 2015). The location-specific crop duration was obtained from the state agricultural departments and commodity research institutes of the Indian Council of Agricultural Research $^{4}$. The amount of fuel consumed for tillage operations under conventional transplanting, DSR, and MTR was based on field records of CIMMYT's on-station and onfarm trials.

\subsection{Women's involvement in rice cultivation}

Using the same cost of cultivation data obtained from the Ministry of Agriculture and Farmers Welfare, ${ }^{5}$ the total labor requirement for rice cultivation was calculated. Women's contribution to rice cultivation was calculated using a household survey conducted by CIMMYT in the 16 districts of the major rice-growing states of India. ${ }^{6}$ Transplanting accounts for about $35 \%$ of

\footnotetext{
${ }^{1}$ The Ministry of Agriculture and Farmers Welfare within the Government of India collects various aspects of data in the field of agriculture across the country (https://eands.dacnet.nic.in/Cost_of_Cultivation.htm). The calculation uses various criteria and assumptions pertaining to cost of human, bullock, machinery labor, agricultural inputs, depreciation of implements and farm buildings, farm revenues, working capitals, and so on (see for details https://eands.dacnet.nic.in/Cost_Concept/Cost_Con.pdf).

${ }^{2}$ https://aps.dac.gov.in/APY/Public_Report1.aspx

${ }^{3} \mathrm{https}$ //bigladdersoftware.com/epx/docs/8-3/auxiliary-programs/koppen-climate-classification.html

${ }^{4}$ ICAR, https://icar.org.in/

${ }^{5}$ https://eands.dacnet.nic.in/Cost_of_Cultivation.htm

${ }^{6}$ CIMMYT dataset: https://data.cimmyt.org/dataverse/csisadvn
} 


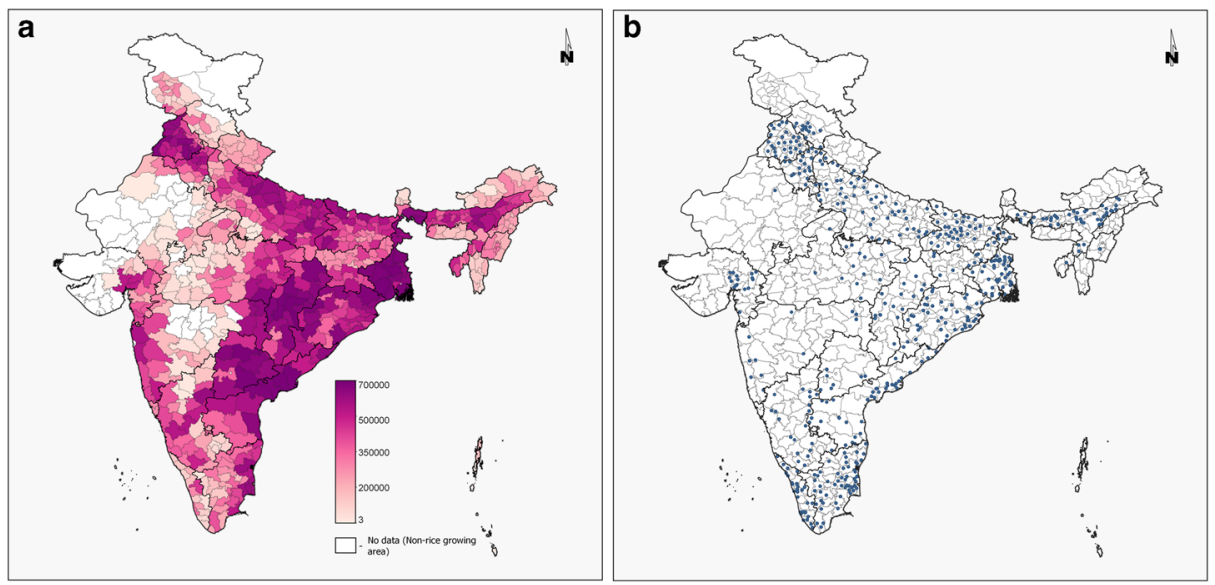

Fig. 1 a Distribution of cultivated rice area (ha) in India. b Distribution of plot-level sample points in riceproducing hotspots

the total labor required for rice cultivation ranging from $23 \%$ (in Haryana where farm mechanization is high) to $48 \%$ (in Uttar Pradesh, where conventional rice cultivation is widespread). Overall, women contribute about $60 \%$ of the total labor required for rice transplanting ranging between $29 \%$ in Haryana and $81 \%$ in Tamil Nadu (Supplementary Table ST1). This proportion was used to estimate women's labor contribution to rice transplanting across all districts in India. The total rice cultivation area and women's contribution to rice transplanting were mapped for 641 rice-growing districts. Subsequently, these 641 districts were used for further analysis of mitigation and women's labor reduction potentials under the different methods of rice cultivation.

\subsection{Estimation of mitigation potential under different rice transplanting methods}

We used CCAFS' Mitigation Options Tool (CCAFS-MOT) (Feliciano et al. 2017) to estimate the GHG emissions under conventional transplanting (CTR), DSR, and MTR. The tool makes use of several empirical models to estimate GHG emissions, considering all the factors that influence GHG emissions, such as soil, climate, production inputs, and management practices. We estimated spatially explicit GHG emission under CTR, DSR, and MTR using respective inputs and management data supplemented with soil and climatic data for all 11,987 data points. District-wise average emission was calculated by averaging the emission values of all sample points within each district. The average emission for the districts with no data points (due to lack of crop management data) was predicted by averaging the emission values of all other districts in the respective states. Ten states (Rajasthan, Chandigarh, Jammu and Kashmir, Goa, Dadra and Nagar Haveli, Sikkim, Arunachal Pradesh, Nagaland, Mizoram, and Meghalaya), together covering $2 \%$ of the total rice-growing area in India, did not have any sampled data points. They were assigned the average emissions from neighboring states with similar agro-climatic conditions. The total emission for each district was calculated by multiplying average emissions with the corresponding rice cropped area.

The mitigation potential of MTR and DSR was determined by subtracting emission under these technologies from that of CTR (Table 1). While CTR can be replaced either by MTR or DSR or both, the paper presents the GHG mitigation potentials of either MTR or DSR under 
the practical replacement scenarios $(5-10 \%)$, but not a combination of them. All GHG emissions and mitigation potentials were converted into $\mathrm{CO}_{2}$ equivalents $\left(\mathrm{CO}_{2} \mathrm{e}\right)$ using the global warming potential (over 100 years) of 28 and 265 times for $\mathrm{CH}_{4}$ and $\mathrm{N}_{2} \mathrm{O}$, respectively (IPCC 2013).

\subsection{Estimation of drudgery reduction potential}

We used the labor replacement potential of two rice production technologies (DSR and MTR) as an indicator for estimating the drudgery reduction for women and men in rice cultivation. Labor use, as such, may not be equivalent to drudgery, but could be the first step towards the associated drudgery. Since drudgery is an outcome of labor use, in this paper, we used the concepts of reduction of women's labor and drudgery interchangeably. We used the following formula to estimate the drudgery reduction potential of two technologies:

$$
\begin{aligned}
\mathrm{LR}= & \text { Total labor for transplanting }(\text { labor }- \text { days } / \text { ha }) \times \text { labor contribution by gender }(\%) \\
& \times \text { labor replaced by the technology }(\%)
\end{aligned}
$$

where LR is the labor replacement.

We consulted the researchers from the ICAR, the CIMMYT, and the International Rice Research Institute (IRRI), working in the main rice-growing areas across the country, about the labor requirements for CTR, MTR, and DSR. We included inputs from five different experts based on their experience in the field. Accordingly, MTR and DSR were estimated to have the potential to reduce $75 \%$ and $92 \%$ of the total labor, respectively (see Supplementary Table ST2 for details). We allocated $60 \%$ labor contribution by women and $40 \%$ labor contribution by men for rice transplanting to estimate drudgery reduction.

\subsection{Mapping mitigation potential and women's drudgery reduction}

The final spatial analysis integrated mitigation potential and women's drudgery reduction across the country. All 641 districts were categorized into four groups based on the emission $\left(\mathrm{tCO}_{2} \mathrm{e}\right)$ reduction potential. All emission reduction potential values under MTR and DSR were normalized between 0 and 1 and created four quartiles. The districts were arranged into four quartiles based on the normalized values: bottom $25 \%(0-0.25), 25-50 \%(0.25-0.50)$, $50-75 \%(0.50-0.75)$, and top $25 \%(0.75-1.0)$. The order ranges from the lowest to the highest total mitigation potential, and the districts falling into first, second, third, and fourth quartiles were plotted separately. The total mitigation potentials in each quartile were summed up separately (Supplementary Fig. SF1a, SF1b). Similarly, women's labor replacement potential values under MTR and DSR were also normalized between 0 and 1 and created four quartiles.

\begin{tabular}{|c|c|c|c|}
\hline Benchmark & Intervention/tillage & $\begin{array}{l}\text { Intervention/water } \\
\text { management }\end{array}$ & $\begin{array}{l}\text { Diesel consumption } \\
\text { (liter/ha) }\end{array}$ \\
\hline Conventional tillage rice & Conventional tillage & Continuous flooding & 55 \\
\hline Machine-transplanted rice & Reduced tillage & Continuous flooding & 30 \\
\hline Direct-seeded rice & Zero tillage & Multiple drainages & 12 \\
\hline
\end{tabular}

Table 1 Tillage, water management, and fuel consumption under various rice cultivation methods

Source: CIMMYT's on-farm trials across the Indo-Gangetic Plains 
The districts were also arranged in the order from the lowest to the highest total women's labor replacement potential, and all quartiles were plotted separately. The total women's laborsaving potentials in each quartile were also summed up separately (Supplementary Fig. SF2a, $\mathrm{SF} 2 \mathrm{~b}$ ). Then, the districts with high mitigation potential and a high potential for women's labor reduction in each quartile were overlaid. Thus, in each quartile, only districts presenting both labor reduction and GHG mitigation potentials were retained.

In the bottom quartile, the districts with the lowest potential of emission and women's drudgery reduction are clustered. The top quartile represents the districts with the highest potential of emission and women drudgery reduction. Similarly, the other two quartiles in the middle represent the districts with the medium potential of emission and women's drudgery reduction, as presented in Section 3 below.

\section{Results}

\subsection{Women's role in rice transplanting}

Figure 2a shows that women's labor contribution to rice transplanting is significantly different by location. More concentration of women's labor force in rice transplanting was observed in the main rice-producing hotspots, especially in the areas with less mechanization, that is, in the eastern coastal states (West Bengal, Odisha, and Andhra Pradesh), Western Maharashtra, and North Indian states (Uttar Pradesh and Bihar). Women's average labor contribution in rice transplanting was estimated as over 32 labor-days per hectare in Maharashtra, West Bengal, and Odisha (Fig. 2b). We estimated that about 814 million women labor-days are required to manually transplant India's total 44 million ha of rice farmlands. Since information on rice transplanting methods is not available, we assumed that all rice production lands in India are currently under the conventional transplanting method. This indicates a large potential to reduce women's drudgery through alternative rice production technologies such as MTR and DSR.
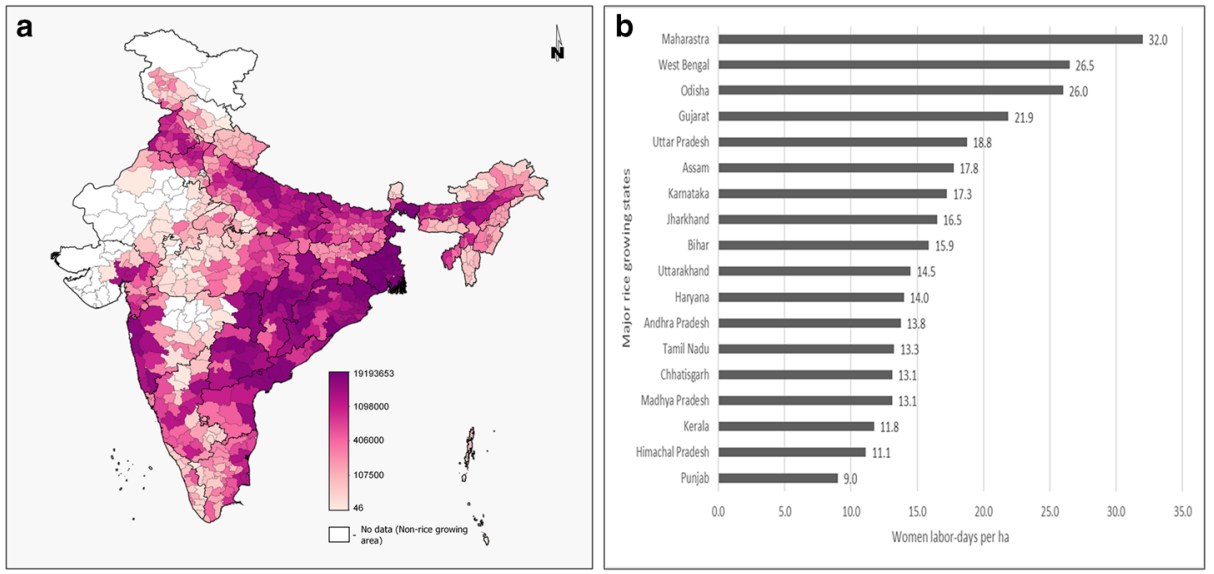

Fig 2 a Distribution of women labor in rice transplanting across India (total labor-days per istrict). b Total women labor hours per ha for rice transplanting in the main rice-growing states. Source: GOI, 2017 


\subsection{Total emissions from the rice-producing hotspots}

Our estimate showed that Madurai, Dindigul, and Tiruppur (Tamil Nadu) are the top three districts with the highest per hectare emission from rice, i.e., 19.4, 14.4, and $14.3 \mathrm{tCO}_{2} \mathrm{e} / \mathrm{ha}$ respectively, followed by Srikakulam (Andhra Pradesh), Thiruvananthapuram (Kerala), and Namakkal (Tamil Nadu) each emitting approximately $9.0 \mathrm{tCO}_{2} \mathrm{e} / \mathrm{ha}$. With current production practices, the total GHG emission from rice production in India is $137 \mathrm{MtCO}_{2} \mathrm{e}$. At the state level, the total emission from rice fields is highest in Andhra Pradesh (29.3 $\mathrm{MtCO}_{2} \mathrm{e}$ from 4.5 million ha), followed by West Bengal (14.1 million $\mathrm{tCO}_{2} \mathrm{e}$ from 5.5 million ha) and Uttar Pradesh (13.9 $\mathrm{MtCO}_{2} \mathrm{e}$ from 5.8 million ha). Rice production-related total GHG emission was the lowest in Sikkim, Rajasthan, and Mizoram.

Figure $3 \mathrm{a}$ and $\mathrm{b}$ present spatial distribution of emission per hectare and total emission, respectively, by districts under CTR. In many districts, emission per hectare is high, which is mainly driven by the intensive use of fertilizer, water, and other production resources. Total emission accounts for emission per hectare multiplied by total rice cultivated area in the districts. Of the top 10 emitter districts, eight were in Andhra Pradesh due to larger acreage under rice cultivation. The other two districts among the top emitters were from West Bengal.

\subsection{Mitigation potential of MTR and DSR}

Total estimated GHG emission from a rice field in India is 137.4, 130.5, and $103.4 \mathrm{MtCO}_{2} \mathrm{e}$ under CTR, MTR, and DSR, respectively (Fig. 4). If CTR is totally replaced by MTR, it can produce $6.9 \mathrm{MtCO}_{2} \mathrm{e}$ less GHG (5\% reduction). Likewise, if CTR is totally replaced by DSR, it can produce $34.0 \mathrm{MtCO}_{2} \mathrm{e}$ less $\mathrm{GHG}$ (25\% reduction) than CTR across all the rice-growing areas of India.

Figure 5 presents the state-wise distribution of potential GHG emission reductions across India under MTR (a) and DSR (b). Andhra Pradesh, Tamil Nadu, and West Bengal have the highest potential for mitigating GHG emissions using DSR technology (10.1 $\mathrm{MtCO}_{2} \mathrm{e}, 4.0$ $\mathrm{MtCO}_{2} \mathrm{e}$, and $3.6 \mathrm{MtCO}_{2} \mathrm{e}$, respectively). In contrast, the top three potential states for reducing
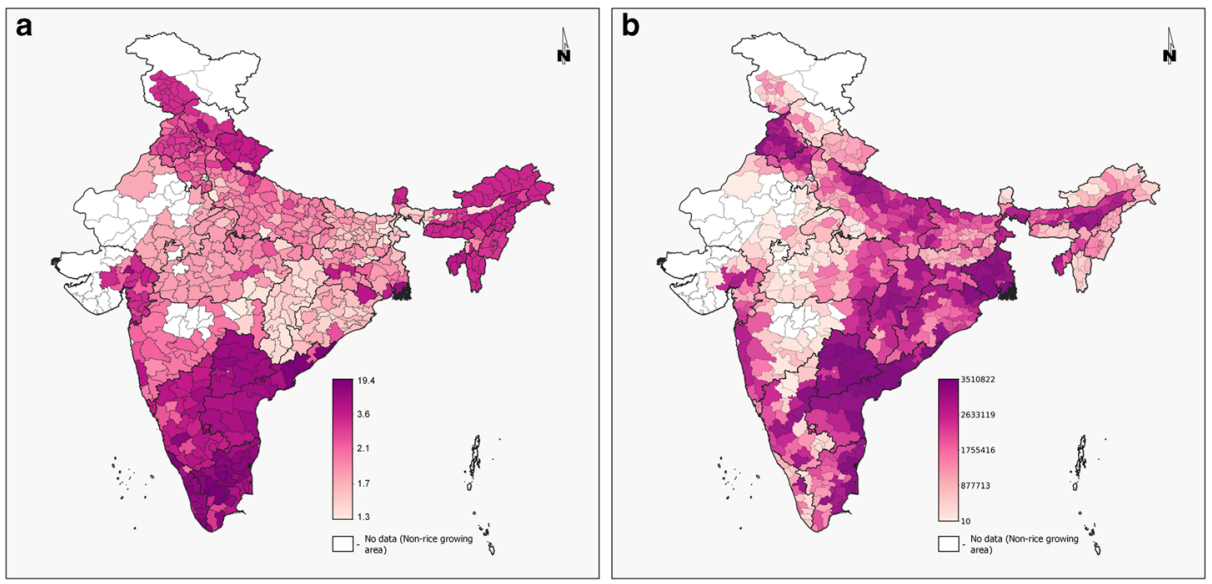

Fig. 3 a Emissions per ha from rice farmlands under CTR across India ( $\mathrm{tCO}_{2} \mathrm{e} / \mathrm{ha}$ ). b Total emission from rice farmlands under CTR across India ( $\mathrm{tCO}_{2} \mathrm{e} /$ district) 


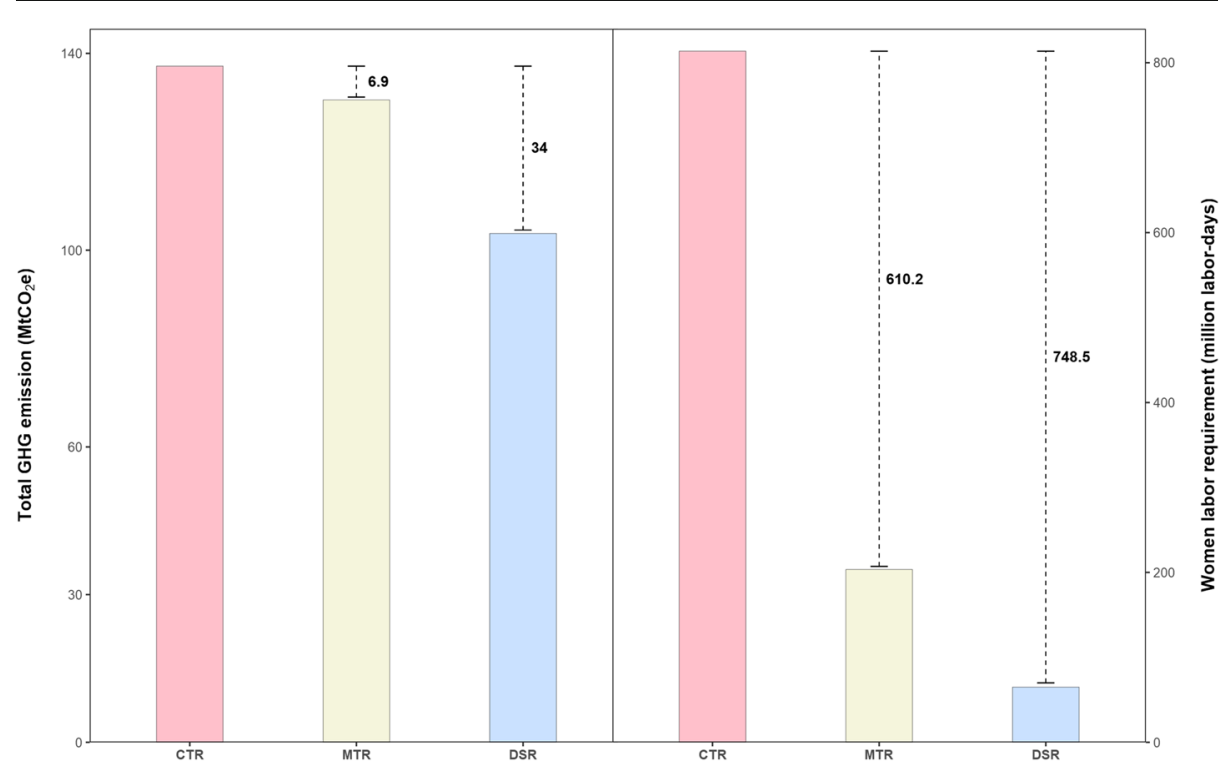

Fig. 4 Total GHG emission (left panel) and women labor requirement (right panel) under conventional tillage rice (CTR), machine-transplanted rice (MTR), and direct-seeded rice (DSR). The dashed lines and associated numbers above MTR and DSR bars show their GHG mitigation and women labor reduction potentials relative to CTR

GHG emissions under MTR are Uttar Pradesh, West Bengal, and Andhra Pradesh (0.95 $\mathrm{MtCO}_{2} \mathrm{e}, 0.88 \mathrm{MtCO}_{2} \mathrm{e}$, and $0.74 \mathrm{MtCO}_{2} \mathrm{e}$, respectively).

\subsection{Potential for women's drudgery reduction from MTR and DSR}

Our estimate shows that rice transplanting alone in the 641 districts of India under CTR requires over 814 million women labor-days. Replacing CTR with MTR and DSR could save 610 and 748 million women labor-days, respectively (Fig. 4, right panel). We also estimated men's labor replacement under MTR and DSR in rice transplanting. The MTR and DSR could
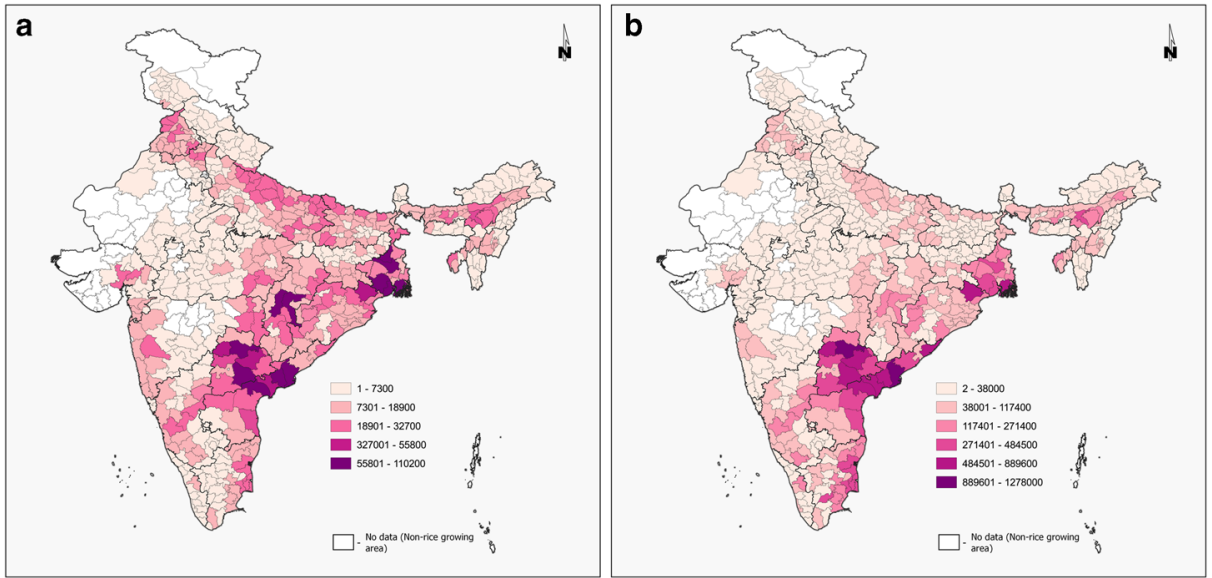

Fig. 5 Distribution of total GHG mitigation potential $\left(\mathrm{tCO}_{2} \mathrm{e}\right)$ of MTR (a) and DSR (b) 
help replace 402 and 494 million men labor-days, respectively. Figure $6 \mathrm{a}$ and b present the distribution of potentials for reducing women's labor under MTR and DSR across India. The highest potentials were estimated in West Bengal (135.8 million labor-days under DSR and 110.7 million labor-days under MTR), followed by Odisha (100.9 million labor-days under DSR and 82.2 million labor-days under MTR), and Uttar Pradesh (100.8 million labor-days under DSR and 82.2 million labor-days under MTR).

\subsection{Women's labor reduction and GHG mitigation potential}

\subsubsection{Machine transplanted rice}

Figure 7 shows the hotspot districts in terms of the potential of machine-transplanted rice (MTR) for both GHG mitigation and women's labor reduction, divided into four groups. The fourth quartile (very high GHG emission as well as women's labor reduction potential) includes 128 districts with a combined potential of reducing $4.1 \mathrm{MtCO}_{2} \mathrm{e}$ and 391 million days of women's labor. The third quartile (high GHG emission as well as women's labor reduction potential) consists of 117 districts with a combined potential of reducing $1.4 \mathrm{MtCO}_{2} \mathrm{e}$ of GHG emission and 108 million days of women's labor. Similarly, the second quartile (medium level of GHG emission as well as women's labor reduction potential) includes 125 districts across India with a combined potential of reducing $0.5 \mathrm{MtCO}_{2} \mathrm{e}$ emissions and 34 million days of women labor. Our study finds that 134 districts fall in the lower quartile with the combined potential to reduce only $0.076 \mathrm{MtCO}_{2} \mathrm{e}$ and five million days of women labor.

The potential of GHG mitigation and women labor reduction of MTR presented in Fig. 7 is under the scenario of $100 \%$ adoption. We disaggregated these numbers in various adoption scenarios $(5 \%, 10 \%, 25 \%, 50 \%$, and $75 \%)$ and compared how they would contribute to reducing GHG emission and women's labor in rice transplanting across the different quartiles in Fig. 7. We started from a scenario of a $5 \%$ adoption rate that could be short- to medium-term goals for the corresponding state governments to contribute to the sustainable development goals (SDG) by 2030 . Under the $5 \%$ adoption rate, the top hotspot districts have the potential to reduce $0.21 \mathrm{MtCO}_{2} \mathrm{e}$ of GHG emission while reducing 19.5 million days of women's labor
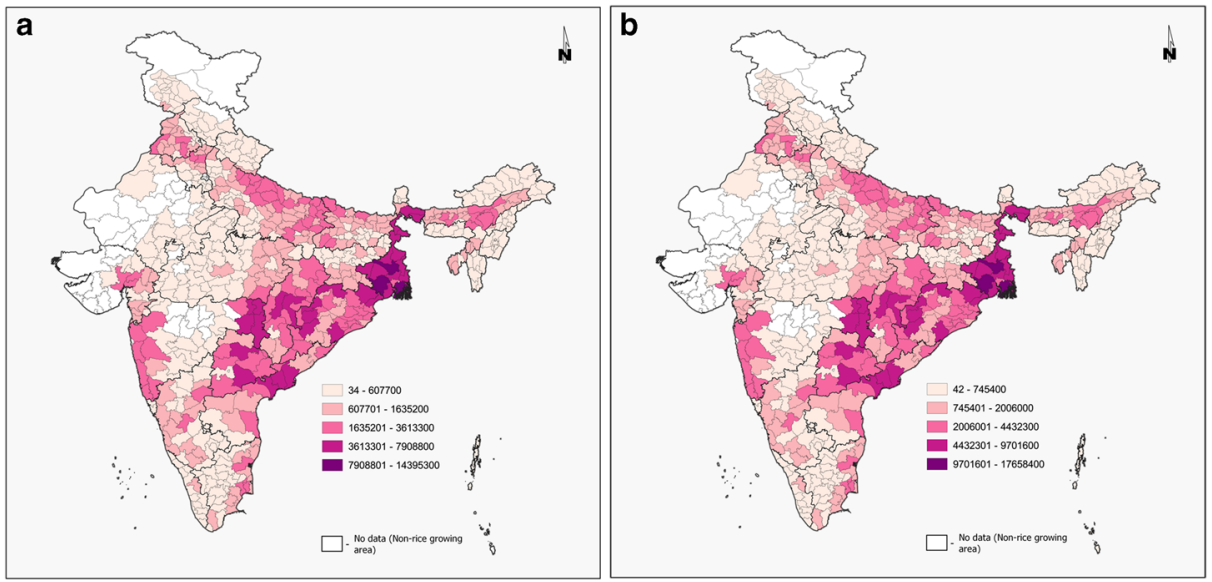

Fig. 6 Distribution of total women labor-saving potential (labor-days) by replacing the conventional method of rice transplanting with MTR (a) and DSR (b) 


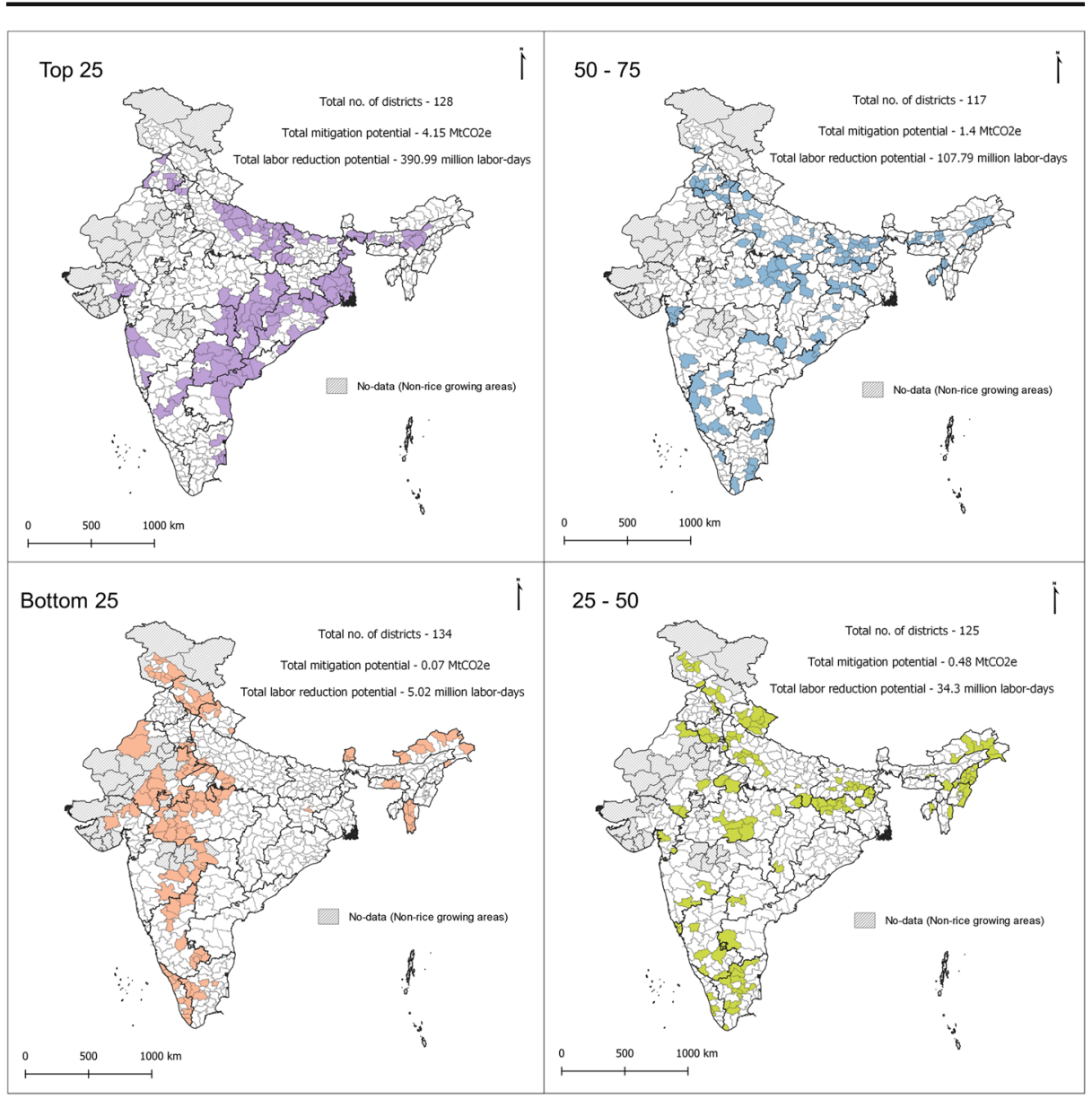

Fig. 7 GHG mitigation and women labor replacement potentials of MTR

by using MTR technology. Under the $10 \%$ adoption rate, which could be a longer-term goal for the state governments (by 2050), the top hotspot districts have the potential to reduce 0.42 $\mathrm{MtCO}_{2} \mathrm{e}$ of GHG emission while reducing 39.1 million days of women's labor from those corresponding districts (see Supplementary Table ST3 for details).

\subsubsection{Direct-seeded rice}

Figure 8 illustrates the hotspot districts for overall gains from direct-seeded rice (DSR) in terms of mitigation and women's labor reduction potentials, divided into four groups. The fourth quartile (very high GHG emission as well as women labor reduction potentials) includes 93 districts with a combined potential of reducing $19.9 \mathrm{MtCO}_{2} \mathrm{e}$ emissions and 397 million days of women labor. The third quartile (high GHG emission as well as women labor reduction potentials) includes 69 districts with combined potential of reducing $2.2 \mathrm{MtCO}_{2} \mathrm{e}$ emissions and 86 million days of the women labor force. Similarly, the second quartile (medium level of GHG emission as well as labor reduction potentials) includes 87 districts across India with a combined potential of reducing $1.0 \mathrm{MtCO}_{2} \mathrm{e}$ emission and 30 million days of women labor. 
Our study finds that 118 districts fall in the lower quartile with the combined potential to reduce only $0.21 \mathrm{MtCO}_{2} \mathrm{e}$ and five million days of women labor.

Again, the potential of GHG mitigation and women labor reduction of DSR presented in Fig. 8 is under the scenario of $100 \%$ adoption. Using the same scenarios and procedure as for MTR, under the $5 \%$ adoption rate, the top hotspot districts have the potential to reduce 0.99 $\mathrm{MtCO}_{2} \mathrm{e}$ of GHG emission while reducing 19.8 million days of women labor from those corresponding districts by using DSR technology. Similarly, under the $10 \%$ adoption rate, the top hotspot districts have the potential to reduce $1.99 \mathrm{MtCO}_{2} \mathrm{e}$ of $\mathrm{GHG}$ emission while reducing 39.7 million days of women labor from those corresponding districts (see Supplementary Table ST4 for details).

\subsection{Priority hotspots for GHG mitigation and women's labor reduction}

We identified the most significant hotspot districts in terms of the dual benefits of GHG mitigation and reduction of women's labor in rice transplanting. It is important to note that gains depend on the level of adoption of the suggested technologies. While details of

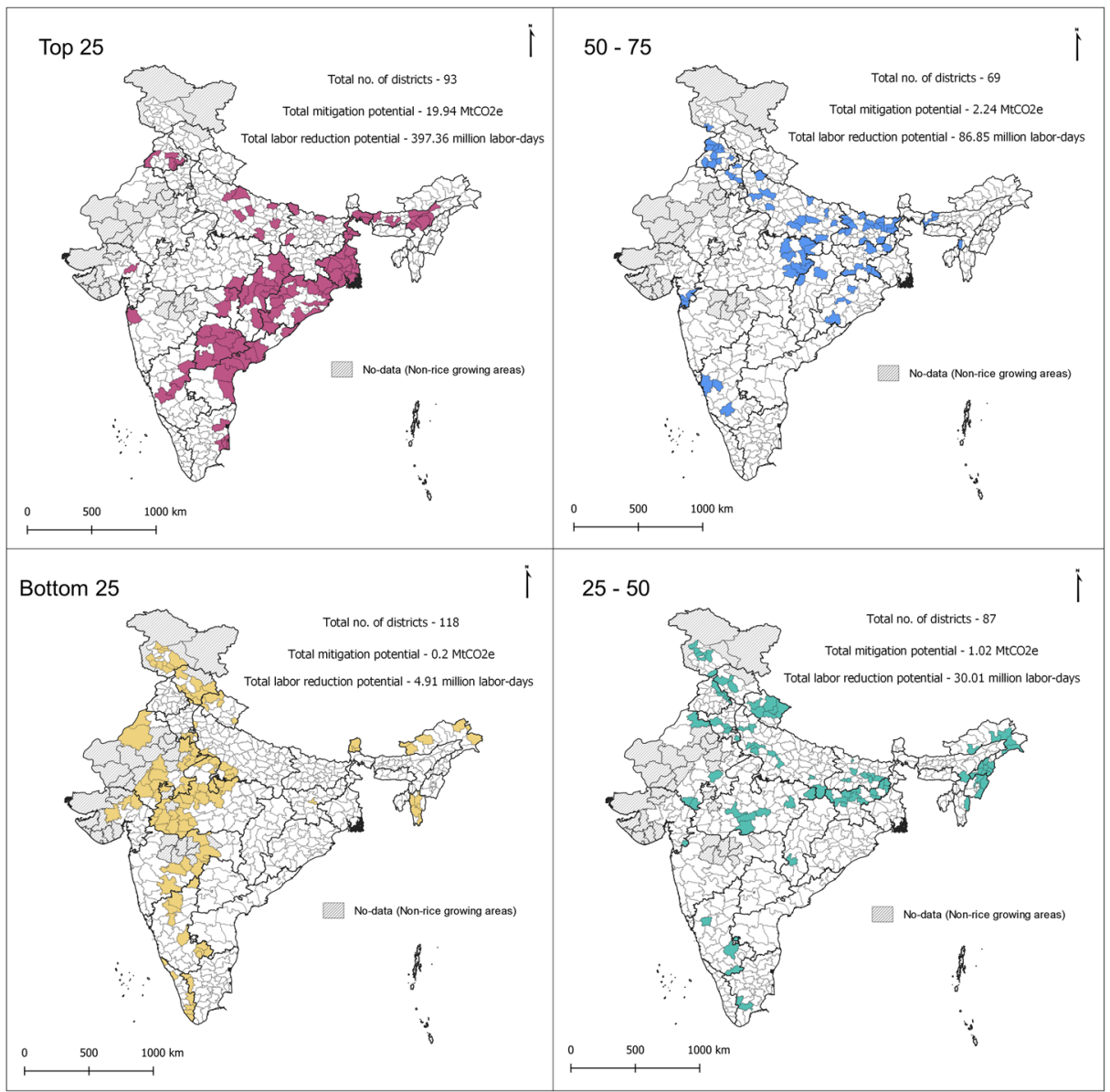

Fig. 8 GHG mitigation and women labor replacement potentials of DSR 
individual districts are provided in the Supplementary Tables (ST5 and ST6 respectively for MTR and DSR), here we discuss the districts that fall in the fourth quartile (highest potential for both GHG mitigation and reduction of women's labor). We identified 128 districts for MTR and 93 for DSR in that quartile.

As priority hotspots for policy relevance under 5\% adoption, West Bengal would benefit most by saving 42.2 million women labor-days and 363 thousand tonne (kt) $\mathrm{CO}_{2} \mathrm{e}$ GHG emissions due to change in the cultivation practices from CTR to MTR. Andhra Pradesh would be the second state to benefit most with the potential of saving 10 million women labordays and $139 \mathrm{ktCO}_{2} \mathrm{e}$ GHG emissions. Chhattisgarh would rank third with the potential of saving 8.7 million women labor-days and $141 \mathrm{ktCO}_{2} \mathrm{e}$ GHG emissions (Table 2, also see Supplementary Table ST5).

In the case of DSR under the same 5\% adoption scenario, the state that would benefit most is Andhra Pradesh with the saving potentials of 46.5 million women labor-days and 8.3 $\mathrm{MtCO}_{2} \mathrm{e}$ GHG emissions from the 12 districts. West Bengal would be the second state to benefit most with the potential of saving 19.3 million women labor-days and $1.1 \mathrm{MtCO}_{2} \mathrm{e}$ GHG emissions from the two districts. Odisha would rank the third with the potential of saving 7.4 million women labor-days and $484 \mathrm{ktCO}_{2} \mathrm{e}$ GHG emissions from the only one Mayurbhanj district (Table 3, also see the Supplementary Table ST6).

\section{Discussion and implications}

In this paper, we estimated the district-wise GHG emissions from conventional rice production technology and mapped the hotspot areas across India. We also calculated the potentials for reducing emissions and women's labor use by changing from conventional technology to MTR and DSR.

\subsection{Mitigation of GHG emissions in rice cultivation}

Higher GHG emission per hectare in the southern states such as Tamil Nadu and Andhra Pradesh (Fig. 3a) was probably due to more intensive irrigation creating anaerobic conditions and low soil $\mathrm{pH}$, favorable for $\mathrm{CH}_{4}$ emission. Through statistical analysis of major variables controlling methane emission, Yan et al. (2005) reported that soil $\mathrm{pH}$ between 4.5 and 5.5 significantly increases $\mathrm{CH}_{4}$ emission from the rice field. Higher emission in northwestern states such as Haryana, Punjab, and Himanchal Pradesh (Fig. 3a) was due to a high level of

Table 2 The top hotspot districts under 5\% adoption scenario (MTR)

\begin{tabular}{llll}
\hline State & District & $\begin{array}{l}\text { Women labor replacement } \\
\text { potential (million labor-day) }\end{array}$ & $\begin{array}{l}\text { Mitigation potential } \\
\left(\mathrm{MtCO}_{2} \mathrm{e}\right)\end{array}$ \\
\hline West Bengal & Pashchim Medinipur & 14.40 & 0.11 \\
& Barddhaman & 12.13 & 0.09 \\
& South 24 Parganas & 7.91 & 0.09 \\
& Purba Medinipur & 7.81 & 0.07 \\
Chhattisgarh & Raipur & 5.40 & 0.07 \\
Andhra Pradesh & Durg & 4.67 & 0.06 \\
& West Godavari & 4.39 & 0.07 \\
& Karimnagar & 4.36 & 0.07 \\
\hline
\end{tabular}


Table 3 The top hotspot districts under 5\% adoption scenario (DSR)

\begin{tabular}{llll}
\hline State & District & $\begin{array}{l}\text { Women labor replacement } \\
\text { potential (million labor-day) }\end{array}$ & $\begin{array}{l}\text { Mitigation potential } \\
\left(\mathrm{MtCO}_{2} \mathrm{e}\right)\end{array}$ \\
\hline West Bengal & South 24 Parganas & 9.70 & 0.64 \\
Odisha & Purba Medinipur & 9.56 & 0.48 \\
Andhra Pradesh & Mayurbhanj & 7.36 & 0.48 \\
& West Godavari & 5.38 & 0.78 \\
& Karimnagar & 5.35 & 0.89 \\
& East Godavari & 5.18 & 1.28 \\
& Nalgonda & 5.04 & 0.84 \\
& Krishna & 4.65 & 0.72 \\
& Guntur & 4.20 & 0.64 \\
& Nizamabad & 3.34 & 0.55 \\
& Warangal & 3.26 & 0.54 \\
& Sri Potti Sriramulu Nellore & 2.88 & 0.47 \\
& Srikakulam & 2.60 & 0.72 \\
& Khammam & 2.45 & 0.44 \\
& Medak & 2.19 & 0.46 \\
\hline
\end{tabular}

intensification in terms of tillage, irrigation, and fertilizer application in these states compared to other states in India. Higher per hectare emission in northeastern states such as Assam, Arunachal Pradesh, Nagaland (Fig. 3a) was probably due to high rainfall and humid climate throughout rice-growing season, favoring more $\mathrm{CH}_{4}$ emission. $\mathrm{CH}_{4}$ emission constitutes about $80 \%$ of the total GHG emission from rice. Per hectare emission was lower in the states of Rajasthan, Madhya Pradesh, and Gujarat, mainly because of in arid and semi-arid climate, not favoring methane emission.

The comparison of Figs. 1a and $3 \mathrm{~b}$ show that the total area under rice is mainly responsible for higher or lower GHG emission in the Jurisdiction. Higher total emission observed in the districts in Andhra Pradesh, Tamil Nadu, Punjab, and Haryana was due to high per hectare emission as well as more areas under rice. However, higher total emissions in the districts of West Bengal, Uttar Pradesh, and Madhya Pradesh are mainly due to more areas under rice (Fig. 1a) despite relatively lower per hectare emission (Fig. 3a).

Our findings indicate a huge potential for substantially lowering GHG emission under MTR and DSR compared to CTR (Figs. 4, 5). This is linked to the decreased fuel consumption related to reduced tillage and water pumping operations. The customary 34 preparatory tillage operations before rice transplanting under CTR are entirely eliminated under DSR and reduced by at least $50 \%$ in MTR. On average, one tillage operation with a harrow or cultivator consumes about $10 \mathrm{~L}$ of diesel per hectare (CIMMYT's field record). Therefore, the avoidance of one tillage operation is translated into ca. $380 \mathrm{MJ}$ of energy saving and $2.68 \mathrm{kgCO}_{2} \mathrm{e}$ GHG saving per hectare (CCAFS-MoT; Feliciano et al. 2017). The non-requirement of puddling in DSR and MTR also reduces a significant amount of water, thereby reducing the emission associated with water pumping. Furthermore, avoidance of puddling in DSR and MTR facilitates downward percolation of water resulting in aerobic conditions leading to $\mathrm{CH}_{4}$ oxidization, which is then further dissolved in the soil solution (Wassmann et al. 2000). Methane is usually formed only after the soil redox potential is lowered to sufficiently negative values (Masscheleyn et al. 1993), resulting from continuous standing water in the field. Higher GHG mitigation potential of DSR than MTR is due to complete avoidance of preparatory tillage in DSR and more aerobic soil condition than in MTR. 


\subsection{The potential for reducing women's drudgery in rice transplanting}

Overall, we estimated conventional rice transplanting alone in the 641 districts of India to account for over 814 million women labor-days each year. Based on our data, we further estimated that at $100 \%$ adoption of MTR and DSR, women's drudgery in relation to rice transplanting could be reduced by $610(75 \%)$ and 748 (92\%) million labor-days, respectively. Even in a scenario of just $5 \%$ adoption, this represents a huge potential for reducing the back-breaking work of the manual rice transplanting traditionally carried out by many rural women across India. That is mainly due to the non-requirement of transplanting labor under DSR and MTR. Transplanting constitutes the significant portion of total labor consumption in rice production under CTR, and women contribute a significant portion of this labor force (Mohanty et al. 2012; Khatri-Chhetri et al. 2020).

\subsection{Social, economic, and policy implications}

As noted by Chanana-Nag and Aggarwal (2018), 63\% of the 97 million women engaged in India's rural labor force are agricultural laborers. For many of these women, manual rice transplanting is one of the very few, and sometimes only, opportunities for paid work, and often essential to their own and their families' livelihood. While replacing CTR with MTR or DSR would appear to hold promise for landowners in terms of time- and cost- savings related to rice production, for the many poor women and their families, who depend on day-laboring as a source of income, it could be a disaster. In other words, the technologies (MTR and DSR) may have negative consequences to rural women whose livelihoods primarily depend on agricultural wage labor. This calls for a better understanding of the context and think of the solutions that can support women's work in climate change mitigation.

At the same time, though, another large number of women $-37 \%$ of the 97 million women engaged in the rural labor force (Chanara-Nag and Aggarwal, 2018) - essentially work as unpaid family labor. Many of them have limited voice and decision-making power related to productive resources in their households. They often shoulder large reproductive labor burdens in addition to their agricultural labor contributions. For these women, the prospect of drastic drudgery reductions about rice transplanting could be assumed to be very attractive, as also indicated, for example, in a study of household decision-making related to MTR in India, which found that women value MTR more than men do (Gulati et al. 2019). In principle, reducing the time and hard physical effort that women are expected to invest in rice transplanting would reduce their overall workload, which, in turn, could give them more time to pursue other activities, and possibly benefit the health and wellbeing of the women themselves and their families.

Yet, research has shown that women's interests and labor time are often valued less than men's, and that investments in labor-saving technologies often prioritize reductions in men's labor (Doss, 2001; Schwab and Hodjo, 2018). Furthermore, in many contexts, as documented for instance by Theis et al. (2019), women's ability to engage with and benefit from laborsaving mechanization is limited by normative stereotypes that discourage women from operating machines and restrict their physical mobility and social interactions, and by normative expectations of women's deference to male authority. As several studies have found, women's bargaining power is often too limited to influence household adoption decisions (Joshi et al. 2019; Hansda 2017; Rola-Rubzen et al. (2020).

Our findings resonate with other research indicating the DSR can enable savings in irrigation water, labor, energy, and time, including reduction of GHG emissions from rice 
fields (Kumar and Ladha 2011; Pathak et al. 2011). However, the successful implementation of DSR is highly contingent on the biophysical and socioeconomic conditions. In many locations, farmers are reluctant to use DSR due to associated problems in weed control (Kumar et al. 2008; Rao et al. 2007). The change in rice establishment methods, including water and tillage management, leads to changes in weed composition and diversity. The promotion of effective and sustainable weed control methods and practices in DSR is critical.

A major reason for farmers' interest in DSR and MTR is the rising cost and scarcity of labor for conventional rice cultivation (Kumar and Ladha, 2011). Others have found that farm size, economic status of farmers, knowledge about DSR and MTR, and government incentives influence the adoption of these technologies (Yamano et al. 2013; Bhardwaj and Sidana 2017). In any case, DSR and MTR require farmers' investment in seeding and transplanting machines or related services. The cost and timely availability of these, therefore, directly influence adoption (Mishra et al. 2016), including for poorer households who may not afford rental services. Moreover, if machinery needs to be purchased or rented, the investment can reduce liquidity and the money available for other household needs and even put the household in debt. In other words, as the women who work in the fields as unpaid family laborers in India tend to not benefit from the better off-farm households, the degree to which they would benefit from reductions in their drudgery related to transplanting would further more depend on the affordability of the technologies in question.

\section{Conclusion}

This study investigated how the potential for reducing GHG emission and women's drudgery can inform policy and targeting related to the reduction of women's agricultural drudgery and GHG emissions through MTR and DSR. Overall, our findings establish a high potential for reducing GHG emissions by replacing conventional rice transplanting method with machine transplanting (MTR) and direct-seeded rice (DSR). Our findings also establish a high overall potential of these technologies to reduce labor drudgery of women, and in general, related to rice transplanting. Additional benefits associated with MTR and DSR include high cost- and time-savings for farmers; reduced water use, energy, and time; and increased yield. Our study shows that these benefits differ according to agro-climatic regions and levels of intensification, and women's involvement in rice cultivation. It also identifies where the potential for reducing GHG emissions and women's drudgery in rice transplanting is highest, both separately and when combined.

As such, the focus in this paper has been on assessing the potential of the technologies in question to reduce the emission of GHG in rice production and the expenditure of human energy about rice transplanting, much of which is contributed by women. In Section 5, however, we have highlighted the disconcerting flip-side of this potential, namely the potentially disastrous effects on large numbers of poor rural women and their families, who could stand to lose an important income opportunity. Likewise, we have called attention to several factors that may very likely jeopardize benefits to those women, who may indeed welcome a reduction in their rice transplanting drudgery. Thus, from a gender perspective, the proposition of replacing CTR with MTR or DSR represents a clear example of the complex dynamics between opportunities and trade-offs often associated with technological change (Beuchelt and Badstue 2013).

We conclude that the MTR and DSR technologies hold big potential for GHG mitigation, labor savings in a general sense, and many other economic and environmental gains. However, they also 
hold immense potential for significant negative impacts on certain groups lest great care is taken, and further research and development interventions are focused on addressing and mitigating these challenges. Further research, across diverse contexts, to identify how best to address the risks of negative social impacts related to the introduction of MTR and DSR under different conditions will be essential to inform policy and scaling out of the technologies in question.

Supplementary Information The online version contains supplementary material available at https://doi.org/ 10.1007/s10584-020-02941-w.

Authors' contributions Hom Gartaula, Tek B Sapkota, and Arun Khatri-Chhetri conceptualized the idea. Hom Gartaula, Tek B Sapkota, Arun Khatri-Chhetri, and Gokul Prasad analyzed data and prepared the manuscript. All authors revised and finalized the manuscript.

Funding This work was funded by the CGIAR Research Programs on Climate Change, Agriculture, and Food Security (CCAFS) and implemented by the International Maize and Wheat Improvement Center (CIMMYT). CCAFS's work is supported by CGIAR Funding Donors and through bilateral funding agreements. For details, please visit https://ccafs.cgiar.org/donors.

Data availability The GHG mitigation and women's labor reduction potential data for all Indian districts are available in the Supplementary Table 5 and 6 (ST 5 and ST 6).

\section{Compliance with ethical standards}

Ethical approval This article does not contain any studies with human or animal participants performed by any of the authors.

Conflict of interest The authors declare that they have no conflict of interest.

Open Access This article is licensed under a Creative Commons Attribution 4.0 International License, which permits use, sharing, adaptation, distribution and reproduction in any medium or format, as long as you give appropriate credit to the original author(s) and the source, provide a link to the Creative Commons licence, and indicate if changes were made. The images or other third party material in this article are included in the article's Creative Commons licence, unless indicated otherwise in a credit line to the material. If material is not included in the article's Creative Commons licence and your intended use is not permitted by statutory regulation or exceeds the permitted use, you will need to obtain permission directly from the copyright holder. To view a copy of this licence, visit http://creativecommons.org/licenses/by/4.0/.

\section{References}

Akter S, Rutsaert P, Luis J et al (2017) Women's empowerment and gender equity in agriculture: a different perspective from Southeast Asia. Food Policy 69:270-279. https://doi.org/10.1016/j.foodpol.2017.05.003

Aryal JP, Rahut DB, Sapkota TB et al (2020) Climate change mitigation options among farmers in South Asia. Environ Dev Sustain 22:3267-3289. https://doi.org/10.1007/s10668-019-00345-0

Balaine N, Carrijo DR, Adviento-Borbe MA, Linquist B (2019) Greenhouse gases from irrigated rice systems under varying severity of alternate-wetting and drying irrigation. Soil Sci Soc Am J 83:1533-1541. https:// doi.org/10.2136/sssaj2019.04.0113

Beuchelt TD, Badstue L (2013) Gender, nutrition- and climate-smart food production: opportunities and tradeoffs. Food Secur 5:709-721. https://doi.org/10.1007/s12571-013-0290-8

Bhardwaj S, Sidana BK (2017) Factors influencing adoption of direct seeding of rice technology in Punjab agriculture. Int J Innov Res Sci Technol 4:252-258 
Bhatia A, Jain N, Pathak H (2013) Methane and nitrous oxide emissions from Indian rice paddies, agricultural soils and crop residue burning. Green Gases Sci Technol 3:196-211. https://doi.org/10.1002/ghg.1339

Chakraborty D, Ladha JK, Rana DS et al (2017) A global analysis of alternative tillage and crop establishment practices for economically and environmentally efficient rice production. Sci Rep 7:1-11. https://doi.org/10. 1038/s41598-017-09742-9

Chanana-Nag N, Aggarwal PK (2018) Woman in agriculture, and climate risks: hotspots for development. Clim Chang. https://doi.org/10.1007/s10584-018-2233-z

Connor M, San SS (2020) Sustainable rice farming and its impact on rural women in Myanmar. Dev Pract, 0(0), 1-10. https://doi.org/10.1080/09614524.2020.1787350

Das FC (2012) Status and prospectus of mechanization in rice. Rice Knowledge Management Portal, Hyderabad, India

Datta A, Rustagi P (2012) Status of women in Bihar: exploring transformation in work and gender relations. Institute for Human Development

Doss CR (2001) Designing agricultural technology for African women farmers: lessons from 25 years of experience. World Dev 29:2075-2092

FAO (2017) FAOSTATS - Agricultural emissions

FAO (2019) FAOSTATS - Rice cultivation

FAO (2020) FAOSTATS - Agricultural emissions

Farooq M, Siddique KHM, Rehman H et al (2011) Rice direct seeding: experiences, challenges and opportunities. Soil Tillage Res 111:87-98. https://doi.org/10.1016/J.STILL.2010.10.008

Feliciano D, Nayak D, Vetter SH et al (2017) CCAFS Mitigation Option Tool. CGIAR, Montpillier

Gathala MK, Ladha JK, Kumar V et al (2011) Tillage and crop establishment affects sustainability of South Asian rice-wheat System. Agron J 103:961-971. https://doi.org/10.2134/agronj2010.0394

GRiSP (2013) Rice almanac. Global Rice Science Partnership, International Rice Research Institute, Los Banos, Philippines

Gulati K, Ward PS, Lybbert TJ, Spielman DJ (2019) Intrahousehold valuation, preference heterogeneity, and demand for an agricultural technology in India. Future of Work in Agriculture Conference, Washington

Gupta PK, Gupta V, Sharma C, Das SN, Purkait N, Adhya TK, Pathak H, Ramesh R, Baruah KK, Venkatratnam L, Singh G, Iyer CSP (2009) Development of methane emission factors for Indian paddy fields and estimation of national methane budget. Chemosphere 74:590-598. https://doi.org/10.1016/J. CHEMOSPHERE.2008.09.042

Gupta DK, Bhatia A, Kumar A et al (2016) Mitigation of greenhouse gas emission from rice-wheat system of the Indo-Gangetic plains: through tillage, irrigation and fertilizer management. Agric Ecosyst Environ 230:1-9. https://doi.org/10.1016/J.AGEE.2016.05.023

Hansda R (2017) Small-scale farming and gender-friendly agricultural technologies: the interplay between gender, labour, caste, policy and practice. Gend Technol Dev 21(3):189-205

Hengl T, Mendes de Jesus J, Heuvelink GBM et al (2017) SoilGrids250m: global gridded soil information based on machine learning. PLoS One 12:e0169748. https://doi.org/10.1371/journal.pone.0169748

Huke RE, Huke EH (1997) Rice area by type of culture. International Rice Research Institute, Los Banos

IPCC (2013) Climage Change 2013: the physical science basis. Intergovernmental Panel for Climate Change (IPCC)

IPCC (2019) Special report on climate change desertification, land degredation, sustainable land management, food security, and greenhouse gas fluxes in terrestrial ecosystems: summary for policymakers. Geneva, Switzerland

IUCN (2015) Gender and climate change: strengthening climate action by promoting gender equality. 21-22

Jat RK, Sapkota TB, Singh RG et al (2014) Seven years of conservation agriculture in a rice-wheat rotation of Eastern Gangetic Plains of South Asia: yield trends and economic profitability. F Crop Res 164:199-210. https://doi.org/10.1016/j.fcr.2014.04.015

Jat HS, Kumar P, Sutaliya JM et al (2019) Conservation agriculture based sustainable intensification of basmati rice-wheat system in North-West India. Arch Agron Soil Sci 65:1370-1386. https://doi.org/10.1080/ 03650340.2019 .1566708

Joshi PK, Khan MT, Kishore A (2019) Heterogeneity in male and female farmers' preference for a profitenhancing and labor-saving technology: the case of direct-seeded rice (DSR) in India. Canadian Journal of Agricultural Economics/Revue canadienne d'agroeconomie 67(3):303-320

Kamboj BR, Yadav DB, Yadav A et al (2013) Mechanized transplanting of rice (Oryza sativa L.) in nonpuddled and no-till conditions in the rice-wheat cropping system in Haryana, India. Am J Plant Sci 04:2409-2413. https://doi.org/10.4236/ajps.2013.412298

Khatri-Chhetri A, Regmi PP, Chanana N et al (2020) Potential of climate-smart agriculture in reducing women farmers' drudgery in high climatic risk areas. Clim Chang 158(1):29-42. https://doi.org/10.1007/s10584018-2350-8

Kumar V, Ladha JK (2011) Direct seeded rice: recent developments and future research needs. Adv Agron 111: 297-413. https://doi.org/10.1016/B978-0-12-387689-8.00001-1 
Kumar V, Bellinder RR, Gupta RK et al (2008) Role of herbicide-resistant rice in promoting resource conservation technologies in rice-wheat cropping systems of India: a review. Crop Prot 27:290-301. https://doi.org/10.1016/j.cropro.2007.05.016

Kumar A, Nayak AK, Mohanty S, Das BS (2016) Greenhouse gas emission from direct seeded paddy fields under different soil water potentials in Eastern India. Agric Ecosyst Environ 228:111-123. https://doi.org/10. 1016/j.agee.2016.05.007

Kumar S, Srivastava AK, Mishra SB, Chaudhary RC (2018) Reducing drudgery of farm women through appropriate farm implements in Uttar Pradesh, India. Int J Agric Sci 10:5761-5764

Masscheleyn PH, Delaune RD, Patrick WH (1993) Methane and nitrous oxide emissions from laboratory measurements of rice soil suspension: effect of soil oxidation-reduction status. Chemosphere 26:251-260

Mishra AK, Khanal AR, Pede V (2016) Economic and resource conservation perspectives of direct-seeded rice planting method: evidence from India. In: Agricultural and Applied Economics Association's 2017 AAEA Annual Meeting. Chicago, IL

Mishra AK, Khanal AR, Mohanty S (2017) Gender differentials in farming efficiency and profits: the case of rice production in the Philippines. Land Use Policy 63:461-469. https://doi.org/10.1016/j.landusepol.2017.01.033

Mohanty SK, Mishra JN, Ghosal MK (2012) Ergonomical evaluation of paddy transplanting operations in Odisha. Int J Agric Eng 5:153-157

Ojha P, Kwatra S (2014) Analysis of different paddy transplanting methods in northern India: ergo-economical study. J Appl Nat Sci 6:654-658

Paris TR (1998) Technology and policy needs of poor women in Asian rice farming. Gend Technol Dev 2(2): 187-218. https://doi.org/10.1080/09718524.1998.11909893

Pathak S, Mina U, Kumar V, Jain N (2011) Direct-seeded rice: potential, performance and problems - a review. Curr Adv Agric Sci 3:77-88

Rao AN, Johnson DE, Sivaprasad B et al (2007) Weed management in direct-seeded rice. Adv Agron 93:153255. https://doi.org/10.1016/S0065-2113(06)93004-1

Rickman JF, Mussgnug F, Khanda C, et al (2015) Operational manual for mechanical transplanting of rice

Rola-Rubzen MF, Paris T, Hawkins J, Sapkota B (2020) Improving gender participation in agricultural technology adoption in Asia: from rhetoric to practical action. Appl Econ Perspect Policy 42:113-125. https://doi.org/10.1002/aepp.13011

Sapkota TB, Jat ML, Aryal JP et al (2015) Climate change adaptation, greenhouse gas mitigation and economic profitability of conservation agriculture: some examples from cereal systems of Indo-Gangetic Plains. J Integr Agric 14:1524-1533. https://doi.org/10.1016/S2095-3119(15)61093-0

Sapkota TB, Vetter SH, Jat ML et al (2019) Cost-effective opportunities for climate change mitigation in Indian agriculture. Sci Total Environ 655:1342-1354. https://doi.org/10.1016/j.scitotenv.2018.11.225

Schwab B, Hodjo M (2018) Who has the time? Gender, labor, and willingness to pay for mechanized technology in Bangladesh and Ethiopia. Presented at 2018 Agricultural and Applied Economics Association Annual Meeting, Washington, DC

Sidhu HSS, Singh M, Singh Y et al (2015) Development and evaluation of the Turbo Happy Seeder for sowing wheat into heavy rice residues in NW India. F Crop Res 184:201-212. https://doi.org/10.1016/j.fcr.2015.07.025

SRD (2020) Area of cultivation of rice in India (2013-2018). Ministry of Statistics and Planning, Government of India

Theis S, Krupnik TJ, Sultana N, et al (2019) Gender and agricultural mechanization: a mixed-methods exploration of the impacts of multi-crop reaper-harvester service provision in Bangladesh. International Food Policy Research Institute (IFPRI), Washington DC

UNFCCC (2019) Differentiated impacts of climate change on women and men: the integration of gender considerations in climate policies, plans and actions; and progress in enhancing gender balance in national climate delegations. Bonn, Germany

Wassmann R, Buendia LV, Lantin RS et al (2000) Mechanisms of crop management impact on methane emissions from rice fields in Los Banos, Philippines. Nutr Cycl Agroecosyst 58:107-119

Yamano T, Baruah S, Sharma R, Kumar A (2013) Factors affecting the adoption of direct-seeded rice in the Northeastern Indo-Gangetic Plain. New Delhi

Yan X, Yagi K, Akiyama H, Akimoto H (2005) Statistical analysis of the major variables controlling methane emission from rice fields. Glob Chang Biol 11:1131-1141. https://doi.org/10.1111/j.1365-2486.2005.00976.x

Publisher's note Springer Nature remains neutral with regard to jurisdictional claims in published maps and institutional affiliations. 